\title{
The attitudes and degree of awareness about MERS-CoV among Saudis of different ages
}

\author{
Shafi Hussain M Alqahtani* and Muteb Nasser R Aldawsari \\ Prince Sattam bin Abdul-Aziz University, Saudi Arabia
}

\begin{abstract}
Background: Middle East respiratory syndrome coronavirus (MERS-CoV) that causes MERS disease was first identified in 2012 in Saudi Arabia. Since that cases have spread within the Kingdom and some cases were transmitted to other Middle Eastern countries, Europe and the United States. However, KSA remains the epicenter of this serious respiratory infection that is associated with high mortality rates. This accentuates the public health concerns because Saudi Arabia receives millions of pilgrims from all over the world.
\end{abstract}

Aims: This study investigated the attitudes and degree of awareness about MERS-CoV among Saudis of different ages.

Patients and methods: Structured anonymous closed ended dichometous questionnaires were distributed to a large population of Saudi men and women of different ages. The questionnaires included questions aboutmodes of transmission of corona virus, clinical features, and outcome of infection, the impact of infection on pilgrimage, methods of prevention, the governmental efforts to combat spread, the availability of information.

Results: Respondents were recruited for the study by random selection. Sixty-eight percent of respondents have good knowledge about the mode of transmission, $82 \%$ were aware about the seriousness of the infection, $51 \%$ responded positively to non availability of curative treatment or vaccine. $74 \%$ knew the modes of prevention and $93 \%$ believed that the government efforts were successful. Of the respondents, $41 \%$ considered MERS-CoV was a serious risk during Hajj or Umrah. Government media, the Saudi Ministry of health posters, radio and television, the social media was the main source of information among young adults and older participants.

Conclusion: The findings suggest that the level of awareness about MERS-Cov in among this Saudipopulation is high and the level of perception reasonable. The governmental health education campaign is critical for increasing MERS-Cov infection awareness.

\section{Introduction}

The "Middle East Respiratory Syndrome Coronavirus" (MERS$\mathrm{CoV}$ ) was first recognized in 2012 as the causative agent for a severe form of respiratory tract infection that is associated with high mortality in some cases [1]. Since it emergence most cases of MERS Cov were clustered Saudi Arabia then cases spread to nearby countries such as Jordan, Qatar, the United Arab Emirates, Oman, and Kuwait. Several imported cases appeared different countries inEurope and North Africa [2,3]. The first United States case of MERS-CoV was confirmed in a person who traveled from Saudi Arabia to USA on the seconf of May 2014 [4].

MERS-CoV is transmitted from patients to close contacts. Infected people also transmit MERS-CoV to others in healthcare settings, such as hospitals [5]. MERS-CoV infection leads to severe acute respiratory illness with fever and dyspnea. Some patients developed gastrointestinal symptoms including diarrhea and nausea/vomiting. Advanced cases had pneumonia and kidney failure. The incubation period for MERS (time between exposure to MERS-CoV and symptoms ranges between 5 to 14 days [6].

The Kingdom of Saudi Arabia is the epicenter of MERS-Cov. As of May 17, 2015, 999 proven cases of who 433 passed away [7]. Pilgrimage is the largest mass gathering in the world as more than 2 million pilgrims and millions of $\mathrm{Mu}$ 'tamirs visit KSA from all over the world. This vast gathering might represent a health risk to the Kingdom. Therefore, it is important to promote the general awareness and knowledge of the public about this serious disease and to implement strict health precautions.

Therefore, this cross-sectional study aim to assess the degree of awareness and the means of transmission and prevention of MERSCov. This study aimed to assess the level of awareness, perception and behavior of a Saudi population towards MERS-Cov infections, and to determine the extent to which their perception of the disease may contribute to support the efforts of the Saudi health authorities to combat this disease.

\section{Methodology}

This was a cross-sectional descriptive study cross-sectional study used a 15-item Arabic, anonymous, closed-ended, dichotomous questionnaire to collect information about to specific knowledge, awareness, perception of perceived seriousness of the disease and, modes of transmission, risk factors, symptoms, fatality rates and its risk to KSA among Saudis of various ages fromschools, hospital, and public placesin Riyadh and Kharj. Some questioners were electronic posted in

Correspondence to: Shafi Hussain M Alqahtani, Prince Sattam bin Abdul-Aziz University, Saudi Arabia, E-mail: drshafialqahtani@gmail.com

Received: August 01, 2015; Accepted: August 26, 2015; Published: August 29, 2015 
social media (whatsapp, twitter, instagram) and some of them.

Thefollowing information was collected: to assess people awareness regarding modes of transmission of MERSCov, its early symptoms, potential risks to KSA, geographic distribution, whether Haj and Umrah represent risks for transmission or if there is a vaccine or treatment for MERSCov. An additional question was added on the source of the information: social media, newspaper, $\mathrm{T}, \mathrm{V}$ or radio. For every question, the participant is given a choice of answering by yes or no.

\section{Sample size}

The sample size was calculated using a Raosoft sample size calculator available at http://www.raosoft.com/samplesize.html. The minimal sample size estimated was 360 individuals we added 20\% to guard against invalid or incomplete responses. A total of 650 questionnaires have been distributed

\section{Date collection and analysis procedure}

Although the questionnaire was anonymous, verbal consent was obtained from all participants. Clear clarification and explanation was given by investigators for each statement and way of filling the questionnaire.

Data analysis was conducted using Statistical Package for SocialSciences version 22.0. Descriptive statistics such as frequency distributions and means were used to evaluate perception variables. The significance level was set at $(\mathrm{p} \leq 0.05)$ for all statistical procedures (Tables 1 and 2).

\section{Results}

In this study, we distributed 630 questioners and received 411

Table 1. The questionnaire structure.

\begin{tabular}{|c|c|}
\hline Question Number & \\
\hline Q1 & \\
\hline Q2 & \\
\hline Q3 & \\
\hline Q4 & \\
\hline Q5 & \\
\hline Q6 & \\
\hline Q7 & \\
\hline Q8 & \\
\hline Q9 & \\
\hline Q10 & \\
\hline Q11 & \\
\hline Q12 & \\
\hline Q13 & \\
\hline Q14 & \\
\hline Q15 & \\
\hline
\end{tabular}

Table 2. Positive answer to five or more questions.

\begin{tabular}{|c|c|c|c|}
\hline $\begin{array}{c}\text { Number of questions with } \\
\text { positive answers }\end{array}$ & Age below 40 & Age above 40 & P value \\
\hline 2 & 28 & 87 & 0.02 \\
\hline 4 & 113 & 121 & 0.02 \\
\hline 6 & 126 & 61 & $<0.001$ \\
\hline 8 & 84 & 56 & 0.03 \\
\hline$<10$ & 77 & 20 & $<0.05$ \\
\hline
\end{tabular}

As shown in table 2, younger participants have better awareness about MERS Cov compared to older individuals.

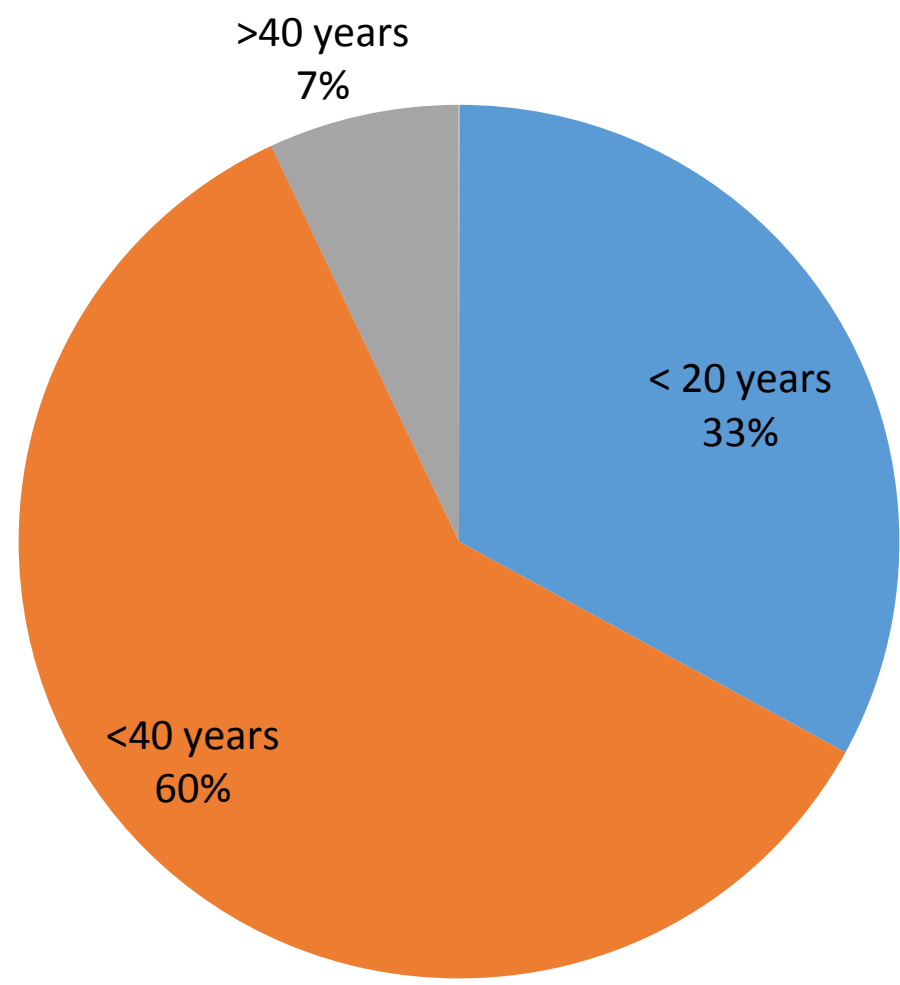

Figure 1. Age distribution of participants.

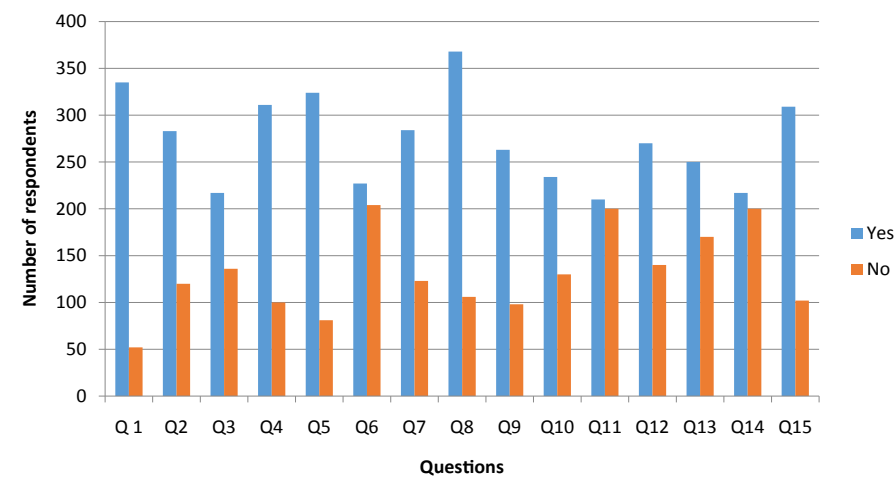

Figure 2. Responses to questions.

responses with a total response rate of $65 \%$. About $68.1 \%$ have secondary school education, $27 \%$ had high level of education. The age distribution for participants is shown in Figures 1-3.

\section{Discussion}

This study assessed the knowledge and attitude of Saudis towards MERSCov in Saudi Arabia and its risks on the public health in the Kingdom.

MERS-CoVthe novel human virus associated with severe respiratory symptoms and renal failure resulted in 999 laboratoryconfirmed infections and 433 deaths in KSA [7]. The transmission of this virus to close contact with an infected individual, such as family members and health care personnel, as well as the associated high mortality rate may represent a major public health threat.

The Saudi Ministry of Health has realized the threats of this disease and is exerting enormous efforts to combat it. Awareness of the public 


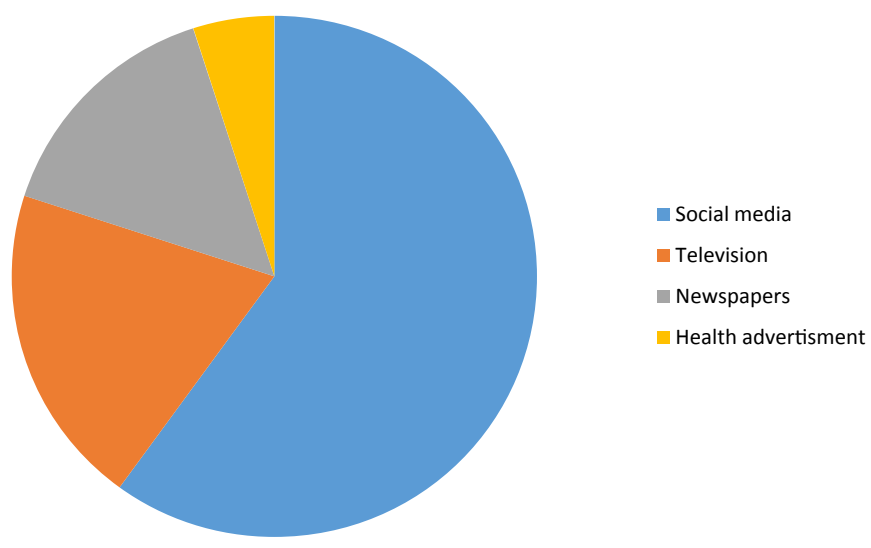

Figure 3. The main source of information.

about the modes of transmission, alerting symptoms and preventive measures is of utmost importance. Furthermore, millions of people come to the Kingdom for Hajj and Umrah it is thus importance to elevate the orientation about the disease.

Therefore, the 411 individuals of different age groups who were invited to complete a questionnaire provided valuable insights to assess the information and knowledge about the MERSCov, and the sources of such information. Overall, participants showed good level of knowledge about sources of infection and prevention. Social medic played a critical role in this knowledge followed by television, news or radio and health advertisements.

The level knowledge was higher particularly among younger participants who derived most of the information from social media. In contrast, older individualsderived knowledge form the TV or radio and few fro newspapers. This suggests that the awareness health campaigns need to include various routes to address different population groups.

\section{Conclusion}

In conclusion, these findings suggest that the level of awareness about MERSCovis good while the level of perception was above average. The robust education campaign of the Saudi Ministry of Health played a critical for increasing MERSCovvirus infection awareness.

\section{References}

1. Bermingham A, Chand MA, Brown CS, Aarons E, Tong C, et al. (2012) Severe respiratory illness caused by a novel coronavirus, in a patient transferred to the United Kingdom from the Middle East, September 2012. Euro Surveill 17:20290. [Crossref]

2. Zaki AM, van Boheemen S, Bestebroer TM, Osterhaus AD, Fouchier RA (2012) Isolation of a novel coronavirus from a man with pneumonia in Saudi Arabia. $N$ Engl $J$ Med 367: 1814-1820. [Crossref]

3. World Health Organization (2014) Middle East respiratory syndrome coronavirus (MERS-CoV) summary and literature update—as of 15 May 2015.

4. Assiri A, McGeer A, Perl TM, Price CS, Al Rabeeah AA, et al. (2013) Hospital outbreak of Middle East respiratory syndrome coronavirus. N Engl J Med 369: 407416.[Crossref]

5. Guery B, Poissy J, el Mansouf L, Séjourné C, Ettahar N, et al. (2013) Clinical features and viral diagnosis of two cases of infection with Middle East Respiratory Syndrome coronavirus: a report of nosocomial transmission. Lancet 381:2265-2272. [Crossref]

6. Health Protection Agency (HPA) UK Novel Coronavirus Investigation team (2013) Evidence of person-to-person transmission within a family cluster of novel coronavirus infections, United Kingdom, February 2013. Euro Surveill 18: 20427. [Crossref]

7. Memish ZA, Zumla AI, Al-Hakeem RF, Al-Rabeeah AA, Stephens GM (2013) Family cluster of Middle East respiratory syndrome coronavirus infections. N Engl J Med 368: 2487-2494. [Crossref]

8. Perera RA, Wang P, Gomaa MR, El-Shesheny R, Kandeil A, et al. (2013) Seroepidemiology for MERS coronavirus using microneutralisation and pseudoparticle virus neutralisation assays reveal a high prevalence of antibody in dromedary camels in Egypt, June 2013. Euro Surveill. [Crossref]

9. Cotten M, Lam TT, Watson SJ, Palser AL, Petrova V, et al. (2013) Full-genome deep sequencing and phylogenetic analysis of novel human betacoronavirus. Emerg Infect Dis 19: 736-742B. [Crossref]

10. vanBoheemen S, de Graaf M, Lauber C, Bestebroer TM, Raj VS, et al. (2012) Genomic characterization of a newly discovered coronavirus associated with acute respiratory distress syndrome in humans. $M$ Bio 3. [Crossref]

11. Ithete NL, Stoffberg S, Corman VM, Cottontail VM, Richards LR, et al. (2013) Close relative of human Middle East respiratory syndrome coronavirus in bat, South Africa. Emerg Infect Dis 19: 1697-1699. [Crossref]

12. Annan A, Baldwin HJ, Corman VM, Klose SM, Owusu M, et al. (2013) Human betacoronavirus 2c EMC/2012-related viruses in bats, Ghana and Europe. Emerg Infect Dis 19: 456-459. [Crossref]

13. Memish ZA, Mishra N, Olival KJ, Fagbo SF, Kapoor V, et al. (2013) Middle East respiratory syndrome coronavirus in bats, Saudi Arabia. Emerg Infect Dis 19: 18191823. [Crossref]

Copyright: (C)2015 Alqahtani SHM. This is an open-access article distributed under the terms of the Creative Commons Attribution License, which permits unrestricted use, distribution, and reproduction in any medium, provided the original author and source are credited. 